\title{
Morphological examination and biogeography of the Gomphonema rosenstockianum and G. tergestinum species complex (Bacillariophyceae)
}

\author{
Maria Helena Novais ${ }^{1,2}$, Saúl Blanco ${ }^{1,3}$, Daša HlúBiková ${ }^{1}$, Elisa Falasco $^{1,4}$, Joan \\ Gomì ${ }^{5}$, Cristina Delgado ${ }^{6}$, Plamen Ivanov ${ }^{7}$, Éva Ács ${ }^{8}$, Manuela Morais ${ }^{2}$, Lucien \\ HOFFMANN $^{1} \&$ Luc ECTOR $^{1}$
}

\author{
${ }^{1}$ Public Research Centre - Gabriel Lippmann, Department of Environment and Agro-Biotechnologies (EVA), 41 \\ ruedu Brill,L-4422 Belvaux,Luxembourg; e-mail:novais@lippmann.lu,ector@lippmann.lu \\ ${ }^{2}$ Laboratório da Água, Instituto de Ciências Agrárias Mediterrânicas, Universidade de Évora, Parque Industrial \\ e Tecnológico, Rua da Barba Rala no 1, P-7005-345 Évora,Portugal; e-mail: hnovais@uevora.pt \\ ${ }^{3}$ Department of Biodiversity and Environmental Management, University of León, E-24071 León, Spain \\ ${ }^{4}$ Università degli Studi di Torino, Laboratorio di Ecologia, Dipartimento di Biologia Animale e dell'Uomo, via \\ Accademia Albertina 13, I-10123 Torino, Italy \\ ${ }_{5}^{5}$ Departament d'Ecologia, Universitat de Barcelona, Av. Diagonal 645, E-08028 Barcelona, Spain \\ ${ }^{6}$ Departamento de Ecología y Biología Animal, Universidad de Vigo, E-36330 Vigo, Spain \\ ${ }^{7}$ Sofia University, Faculty of Biology, 8 Dragan Tzankov blvd, Sofia-1164, Bulgaria \\ ${ }^{8}$ Hungarian Danube Research Station, Hungarian Academy of Sciences, Jávorka S. u. 14, H-2131 Göd, \\ Hungary
}

\begin{abstract}
The type material of Gomphonema rosenstockianum LANGE-BERT. et E. ReICHARDT from La Gomera (Canary Islands, Spain) and epilithic material of rivers from several European countries were examined using light and scanning electron microscopy in order to improve the knowledge on the taxonomical status of the $G$. rosenstockianum and G. tergestinum (GRUNOw) M. Schmidt species complex. Two other Gomphonema species, G. supertergestinum E. REICHARDT and G. angustius E. REICHARDT, recently described and belonging to the same group, are also presented in detail. After the analysis of several populations of G. rosenstockianum and G. tergestinum it was possible to define several reliable criteria to allow morphological differentiation of both species under LM and SEM as well. A geometric morphometric analysis clearly demonstrated the separation of these taxa considering valve outline, size and shape of the central area and position of the stigma. Apart from the morphological analysis, compilation of the results of this study has also revealed differences in ecological preferences of the two species. World and European distribution maps of the four Gomphonema taxa are presented.
\end{abstract}

Key words: diatoms, geometric morphometry, Gomphonema, morphology, type material, ultrastructure

\section{Introduction}

The biraphidaceous, heteropolar diatom genus Gomphonema was erected by EHRENBERG in 1832, and is very common in freshwater haptobenthic communities (Round et al. 1990). Within this genus, the taxonomy of Gomphonema tergestinum (Grunow) M. SCHMIDT and G. rosenstockianum LANGE-Bert. et E. ReICHARDT is considered problematic to the point that these two species are commonly misidentified at first sight, especially under light microscopy (LM).

Gomphonema rosenstockianum was described and illustrated by light and scanning electron microscopy (SEM) in 1993 by LANGEBertalot \& Reichardt from La Gomera, Canary Islands, Spain (Lange-Bertalot 1993). Its occurrence, according to LANGE-BERTALOT (1993), is limited to several slightly alkaline waters from Canary Islands (La Gomera and Tenerife) with moderate conductivity and oligosaprobic to $\beta$-mesosaprobic waters.

Gomphonematergestinum was originally described from Trieste (Italy) by GRUNOw as Gomphonema semiapertum var. tergestina GRUNOW in VAN HeUrck 1880. Afterwards, M. Schmidt drew 8 figures of $G$. tergestinum GRUNOw in SCHMIDT et al. (1902), based on the analysis of samples 
collected in Cresswell (United Kingdom) and in Gülzow, Mecklenburg-Vorpommern (North of Germany). These initial mentions of the taxon (GRUNOw's and SchMIDT's) were only presented by drawings, without providing descriptions. The first morphological description of $G$. tergestinum was published by Hustedt (1930), based on samples collected in standing waters in Gülzow and in Jezioro Śremskie (Poland). Later Krammer \& LANGe-Bertalot (1986) presented a more complete description of its ultrastructure, distribution and ecology. According to KRAMMER \& LANGE-Bertalot (1986), G. tergestinum has been mainly found in oligotrophic to low mesotrophic lakes with high conductivity (e.g. Lago di Garda in the calcareous Southern Alps). More recently, VAN DAM et al. (1994) considered it to be a euryhaline, alkaliphilous, oligosaprobous, oligomesotraphentic and nitrogen-autotrophic taxon, tolerating very low concentrations of organically bound nitrogen. Afterwards, LANGE-BERTALOT (1996) suggested G. tergestinum as a presumably endangered taxon in Germany, occurring in oligotrophic and mainly calcareous water bodies. Distribution of G. tergestinum was not entirely known until 1986, since it has only been found in a few sites in Europe, Asia and North America (Krammer \& Lange-Bertalot 1986). However, considering the currently available references on the occurrence of this taxon, there is a vast set of publications referring to the distribution of this Gomphonema from numerous freshwater sites all around the world (see Fig. 294, world distribution map for detail).

Two other taxa belonging to the same group and whose identification can be problematic due to similarities with $G$. rosenstockianum and G. tergestinum are G. angustius E. REICHARDT and G. supertergestinum E. ReICHARDT. Gomphonema angustius was recently described from Germany (REICHARDT 2009). To date, the occurrence of $G$. angustius, according to REICHARDT (2009), is limited to highly calcareous streams in the Franconian Jura, in the Northern Alps of Switzerland and in Sicily. G. supertergestinum was described from Germany (REICHARDT 2009); this is considered as an independent species although it has already been represented by several authors, e.g. in SCHMIDT et al. (1902), Hustedt (1930), and VAn DER WerfF \& Huls (1957-1974); nevertheless, according to ReICHARDT (2009), in those works it has not been distinguished from G. tergestinum.

The main aim of this study is to increase the knowledge about the taxonomy of the Gomphonema rosenstockianum - G. tergestinum species complex and to document the morphological differences of the species. To achieve this aim we relied on the analysis in LM and SEM of epilithic diatom samples collected in rivers from different European countries and the type material of G. rosenstockianum from Canary Islands, on a valve shape analysis by means of geometric morphometry, and on the verification of the stability of the morphological characters throughout the life cycle of $G$. rosenstockianum through the study of monoclonal cultures from samples collected in South of Portugal streams. Additionally, G. angustius and G. supertergestinum are characterized and illustrated in detail by LM and SEM with additional references to the distribution of both species. Furthermore, it is aimed to present the world distribution of the four species studied through the analysis of bibliographic information and the epilithic samples studied.

\section{Materials and methods}

Observations are based on the original type material of Gomphonema rosenstockianum obtained from the Lange-Bertalot Collection, Eu-E 56, Botanik Institut Universität Frankfurt am Main, collected by H. Grasmück (March 1988) in Bosque del Cedro, La Gomera, Canary Islands, Spain.

The type material of $G$. semiapertum var. tergestina GRUNOw has not been found so far, neither at the Grunow Diatom Collection at the Naturhistorisches Museum Wien (Curator: Dr. Anton Igersheim) nor at the National Botanic Garden of Belgium in Meise (Curator: Dr. Bart Van de Vijver). Thus, Grunow's drawing in plate 25, fig. 40 in VAN HeuRcK (1880) represents the only available information about the type of this species. The drawing of the type of $G$. semiapertum var. tergestina made by A. GRUNOw, M. SchmidT's illustrations of $G$. tergestinum presented in plate 234, figs 41-43 in SchmidT et al. (1902), and the LM and SEM images shown in REICHARDT \& LANGEBertalot (1991) were the basis used to define the concept of the species.

Moreover, epilithic diatom samples from Bulgaria, France, Hungary, Italy, Portugal, Slovakia and Spain were also analysed in LM and SEM. Details of the sampling sites are presented in Table 1. Additionally, monoclonal cultures of $G$. rosenstockianum were obtained from three samples collected in December 2006 from streams of the Algarve, South of Portugal.

Type material, field samples and monoclonal cultures were treated using hot hydrogen peroxide (120 vols.) and diluted $\mathrm{HCl}(37 \%)$, in order to obtain 


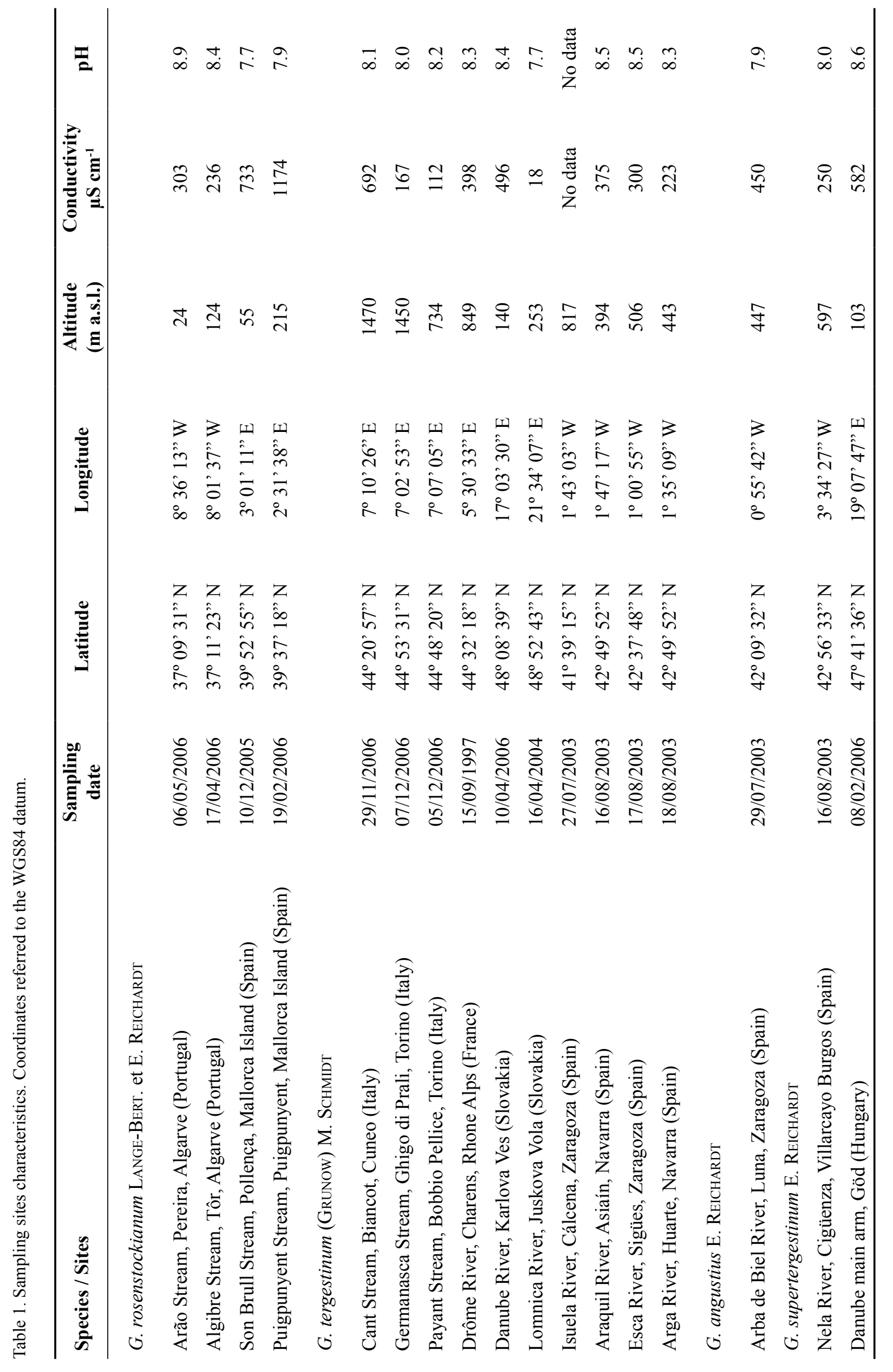


a suspension of clean frustules. Permanent slides were mounted with Naphrax ${ }^{\circledR}$. LM observations and morphometric measurements were performed using a Leica ${ }^{\circledR}$ DMRX light microscope with 100x oil immersion objective and light microscopy photographs were taken with a Leica ${ }^{\circledR}$ DC500 camera. Samples selected for scanning electron microscopy analysis were filtrated through polycarbonate membrane filters with a pore diameter of $3 \mu \mathrm{m}$, mounted on stubs, sputtered with gold (40 nm) with Modular High Vacuum Coating System (BAL-TEC MED 020) and studied with a Leica ${ }^{\circledR}$ Stereoscan $430 \mathrm{i}$, operated at $20 \mathrm{kV}$.

For the valve shape analysis, 15 landmarks were placed along the valve outline and at the curvature extremes, at the end of the striae delimiting the central area, and on the stigma (Fig. 1) and digitized using tps Dig2 software (RoHLF 2004). The Cartesian coordinates of the cells were aligned (translated, rotated and scaled) by the Procrustes generalized orthogonal least-squared superimposition procedure (Generalized Procustes Analysis, GPA, Rohlf \& Slice 1990). Thin-plate spline deformations in landmark configuration relative to a theoretical average configuration representing the consensus form of the valve shape were calculated. A Principal Component Analysis (PCA) was carried out on the tangent space Procrustes coordinates by means of the software Past version 1.78 (HAMmer et al. 2001). Afterwards a Hotelling's T-square statistic was performed on the PCA scores of the specimens in the first two axes to account for significant morphological differences among the a priori established groups, this test being a generalization of Student's t statistic that is used in multivariate hypothesis testing (Hotelling 1931). We evaluated 50 light microscope photographs of $G$. rosenstockianum for the valve shape analysis, including the type material and the populations of the South of Portugal and Mallorca Island (Spain) and 50 light microscope photographs of G. tergestinum from Italy, Slovakia and Spain.

Based on the bibliographic information

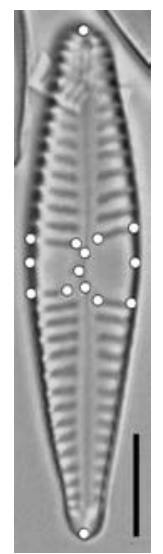

Fig. 1. Light micrograph of Gomphonema tergestinum showing the position of the 15 landmarks on the valve outline used to perform the morphometric analysis. Scale bar $5 \mu \mathrm{m}$. available and on the distribution of the taxa present in the epilithic river samples analysed in this study, a world distribution map of $G$. rosenstockianum, $G$. tergestinum, G. angustius and G. supertergestinum has been performed using GIS software.

\section{Results}

Gomphonema rosenstockianum LANGE-BERT. et E. REICHARDT in LANGe-Bert. 1993 Figs 2-69: LM, Figs 70-79: SEM

References and illustrations

The type of the species has only been illustrated by LANGe-Bertalot (1993, p. 71, pl. 76, figs 1-8: LM, figs 9, 10: SEM).

Morphological examination

Type material: Figs 2-13: LM, Figs 70-74: SEM

Populations from river epilithic samples: Figs 14-69: LM, Figs 75-79: SEM

Specimens of $G$. rosenstockianum were abundant in the type material from Canary Islands and the examination of the type population allowed the definition of the following features: valve outline is always sublinear-elliptic to elliptic in smaller individuals, striae are slightly radiate to almost parallel in the proximity of the central area (Figs 2-13). Only one short stria is located on the stigma-bearing side, on the opposite side to the unilaterally expanded central area (Figs 2-13). The ranges of width, length, and density of striae are given in Table 2. Observed in SEM, the stigma is covered by a papilla and does not present a collar-like ring around its aperture in internal view (Fig. 74), striae consist of one row of areolae although sometimes the areolae can be arranged in a double row in the proximity of the raphe (Fig. 70). Areolae are covered by papillae (Fig. 72).

A comparison between the epilithic samples from South of Portugal (Figs 14-41: LM, Figs 75-79: SEM) and Mallorca, Balearic Islands, Spain (Figs 42-69: LM) with the type material (Canary Island, Spain) showed a constancy of morphological characteristics. Nevertheless, the populations from the river epilithic samples presented smaller individuals and higher density of striae than the type material (Table 2). LM and SEM examination of the monoclonal cultures from stream samples of South of Portugal allowed the observation of the stability of the characteristics 

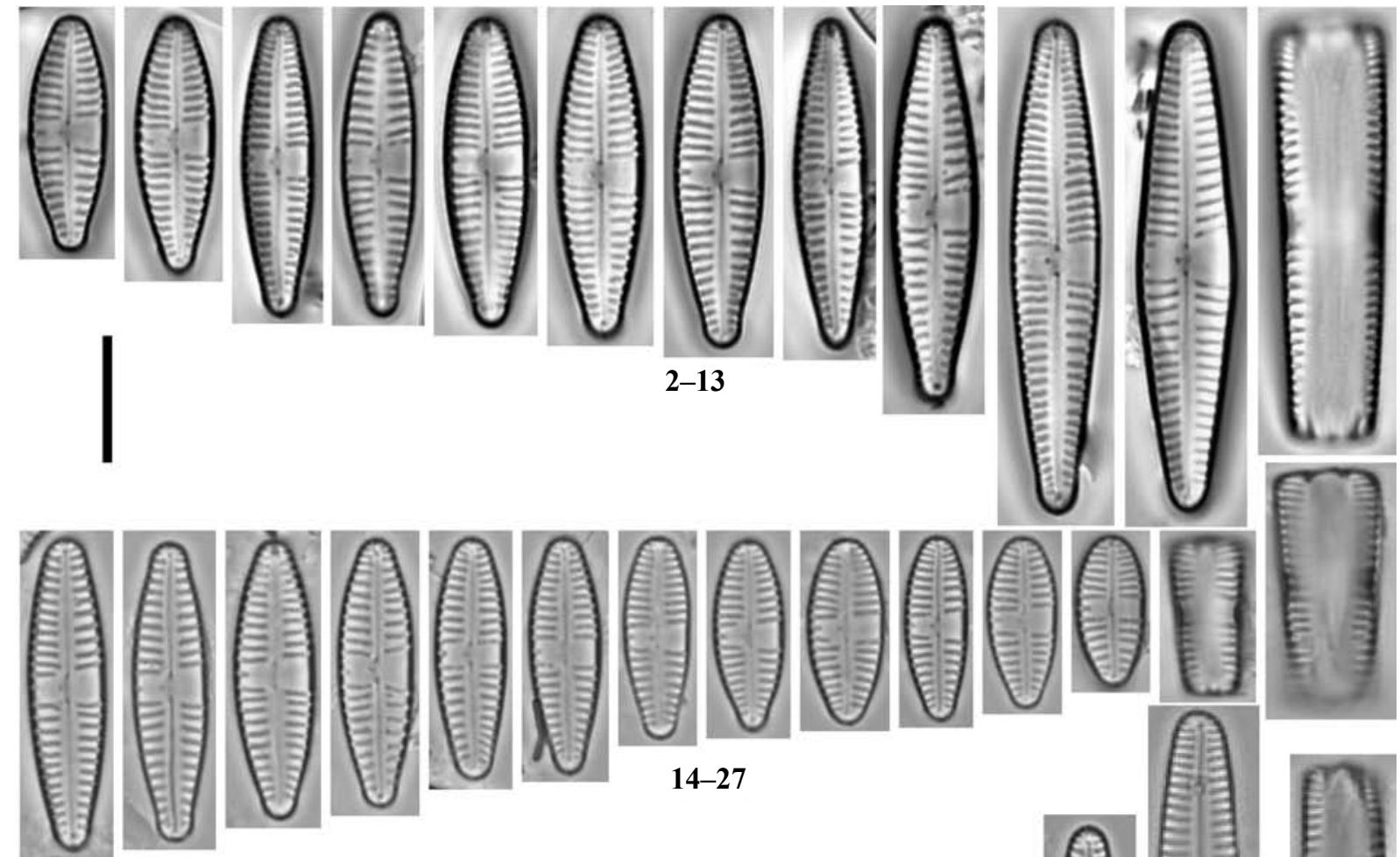

14-27
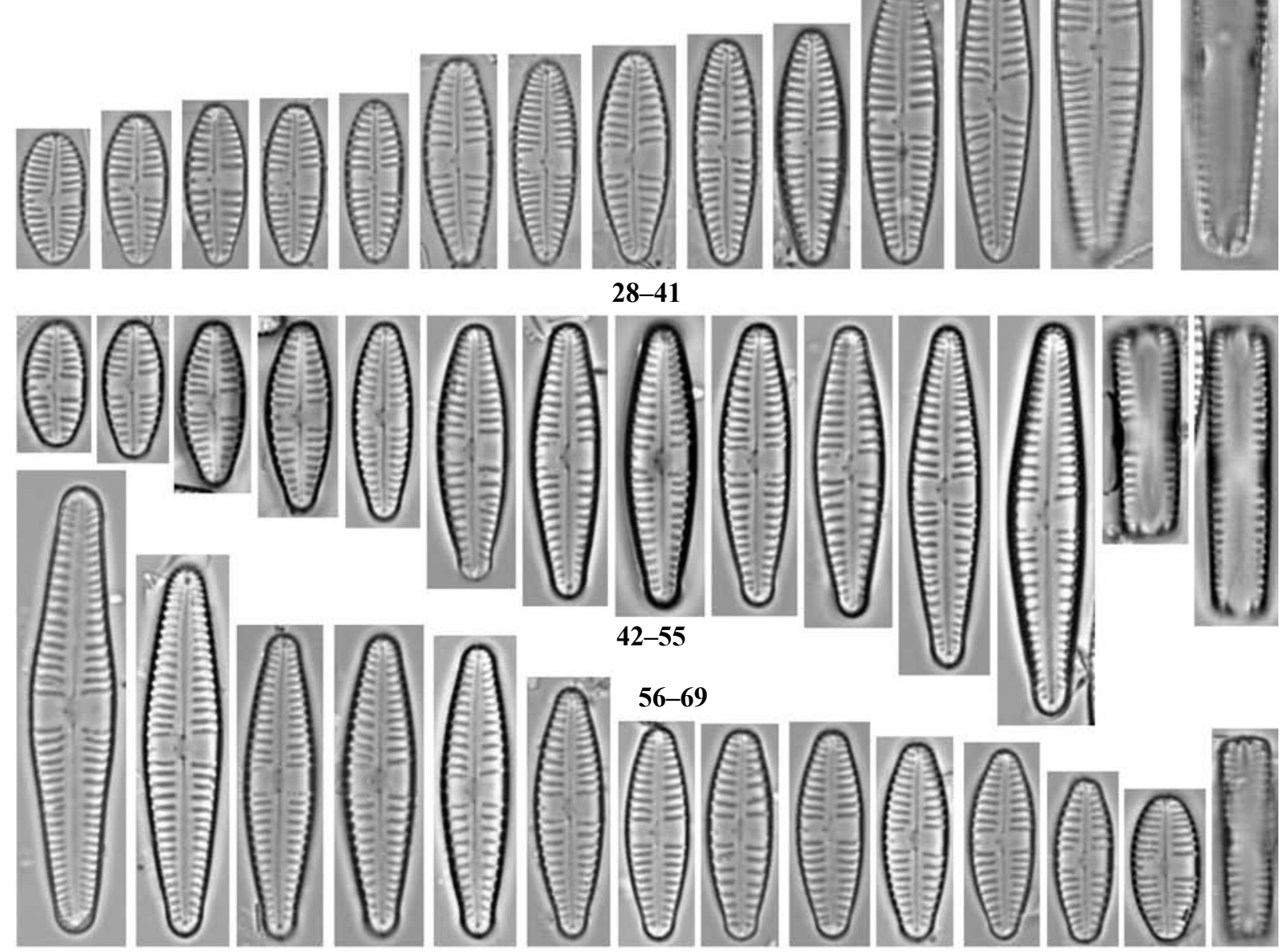

Figs 2-69. Light micrographs of Gomphonema rosenstockianum: (2-13) type material, La Gomera, Canary Islands, Spain; (14-27) Arão Stream, Pereira, South of Portugal; (28-41) Algibre Stream, Tôr, South of Portugal; (42-55) Son Brull Stream, Pollença, Mallorca, Spain; (56-69) Puigpunyent Stream, Puigpunyent, Mallorca, Spain. Scale bar $10 \mu \mathrm{m}$. 

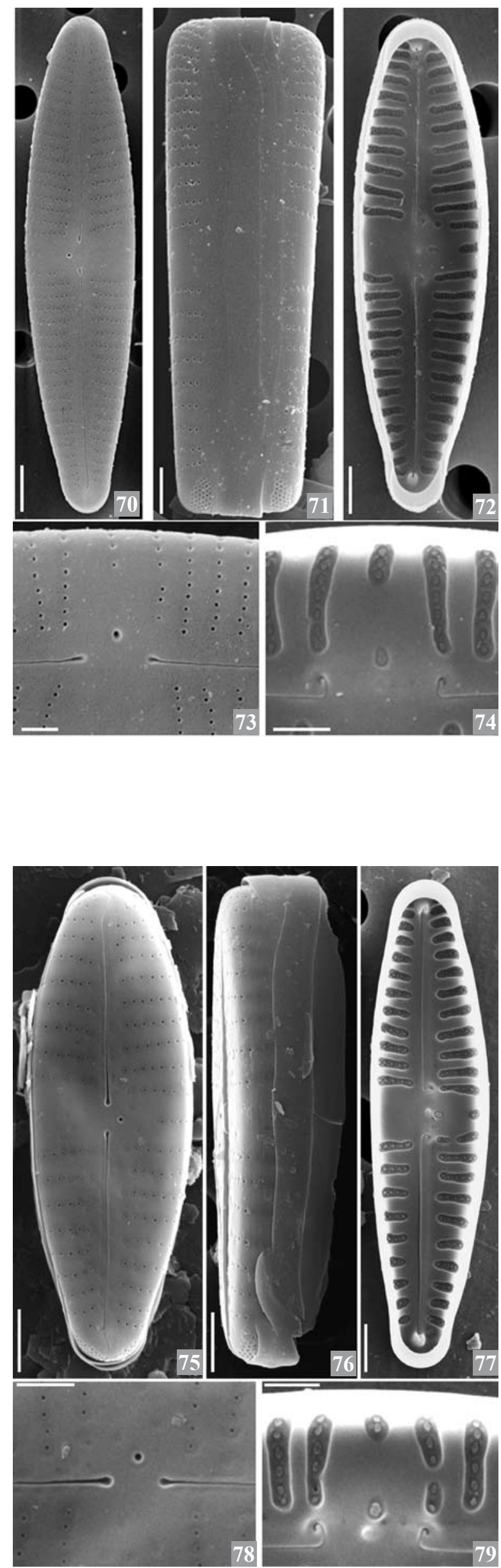

throughout the life cycle. Namely, in LM the valve outline was always sublinear-elliptic to elliptic in smaller individuals, striae were slightly radiate to almost parallel in the proximity of the central area and the presence of only one short stria on the stigma-bearing side, opposite to the unilaterally expanded central area. In SEM, the stigma was covered by a papilla and lacked a collar-like ring around its aperture (in internal view). The striation was formed by one range of areolae internally covered by papillae.

\section{Ecological data}

The geographical and chemical characterization of the sites from where the populations of Gomphonema rosenstockianum illustrated in this study were collected, is presented in Table 1. This epilithic diatom was found with abundance over $2.5 \%$ in several Portuguese streams with a range of $\mathrm{pH}$ between 6.5 and 9.2, conductivity between 146 and $600 \mu \mathrm{S} \mathrm{cm} \mathrm{cm}^{-1}$ and dissolved oxygen between 6.6 and $13.0 \mathrm{mg} \mathrm{l}^{-1}$, while the two streams of Mallorca Island (Spain) with presence of $G$. rosenstockianum are characterized by a $\mathrm{pH}$ between 7.5 and 8.0, a conductivity between $732-1601 \mu \mathrm{S} \mathrm{cm}^{-1}$ and dissolved oxygen between $6.2-10.4 \mathrm{mg} \mathrm{l}^{-1}$.

Gomphonema tergestinum (GRUNOW in VAN Heurck) M. Schmidt in Schmidt et al. 1902

Figs 1, 80-242: LM, Figs 243-252: SEM

Basionym: Gomphonema semiapertum var. tergestina Grunow in VAN Heurck 1880, pl. 25, fig. 40

Nomenclatural synonyms: Gomphonema parvulum var. tergestina (Grunow in VAN Heurck) Cleve 1894,

Figs 70-74. Scanning electron micrographs of the type material of Gomphonema rosenstockianum, La Gomera, Canary Islands, Spain: (70) valvar view (external view); (71) girdle view (external view); (72) valvar view (internal view), showing the uniseriate striation and the areolae covered by papillae; $(73,74)$ details of the central area in external (Fig. 73) and internal (Fig. 74) views. Scale bars (Figs 70-72) 2 $\mu \mathrm{m}$, scale bars (Figs 73, 74) $1 \mu \mathrm{m}$.

Figs 75-79. Scanning electron micrographs of Gomphonema rosenstockianum from Arão Stream, Pereira, South of Portugal: (75) valvar view (external view); (76) girdle view (external view); (77) valvar view (internal view); $(78,79)$ details of the central area in external (Fig. 78) and internal (Fig. 79) views. Scale bars (Figs 75-77) $2 \mu \mathrm{m}$, scale bars (Figs 78, 79) $1 \mu \mathrm{m}$. 
p. 181; G. lanceolatum f. tergestina (GRUNOW) CLEVEEuler 1955, v. 5 (4): p. 185

Infraspecific taxa: Gomphonema tergestinum $\mathrm{f}$. subrostrata MANGUIN 1964, p. 91; pl. 21, fig. 4; Gomphonema tergestinum var. arcaliae ROBERT 1969, v. 14 (2): p. 44; fig. 4a, b; these two infraspecific taxa (MANGuin 1964, Robert 1969) are not similar to the nominate variety and are not included in this study.

References and illustrations

VAN Heurck (1880, pl. 25, fig. 40: drawing, as G. semiapertum var. tergestina GRUNOw), SCHMIDT et al. (1902, pl. 234, figs 41-43: drawings, as G. tergestinum Grunow), CARTER (1960, pl. 2, figs 3-6: drawing, as $G$. tergestinum Grunow), RoBert (1969, p. 44, fig. 3: LM, as G. tergestinum (Grunow) Fricke), Reichardt \& LANGe-Bertalot (1991, pl. 10, figs 14-16: LM, fig. 17: SEM, as G. tergestinum FrICKE), GÜTTINGER (1992, pl. 2.05.24-12, figs 1-6: SEM, as G. tergestinum FrICKE), Lange-Bertalot \& Metzeltin (1996, p. 314, pl. 98, fig. 19: LM, as G. tergestinum Grunow), Sims (1996, pl. 109, fig. 18: drawing, as G. tergestinum (GRUNOw in Van Heurck) Fricke in A. Schmidt), HürlimanN \& NiEDERHAUSER (2007, pl. 21, figs 24-27: LM, as G. tergestinum (Grunow) M. SсHмidT), Levkov et al. (2007, p. 486, pl. 166, fig. 19: LM, as G. tergestinum (Grunow) Fricke), Reichardt (2009, fig. 8: SEM, figs 82-87, 89-92: LM, as G. tergestinum (GRunow) M. SCHMIDT).

\section{Taxonomical remarks}

In SCHMIDT et al. (1902), the asterisks situated near the illustrations of $G$. tergestinum (figs 3943) in the plate 234 (Tafel 234. Herausgegeben von Dr. Friedr. FricKE) indicate that M. SCHMIDT is the author of these drawings in A. SCHMIDT's Diatom Atlas. For this reason, the correct name is G. tergestinum (Grunow) M. Schmidt and not $G$. tergestinum (Grunow) Fricke, as stated in many references, e.g. Hustedt (1930) and LevKov et al. (2007).

\section{Morphological examination}

The ranges of length, width, and density of striae of $G$. tergestinum from the available information on the type material and the river epilithic samples are presented in Table 2. Morphological characteristics of the species, based on the literature and river epilithic populations studied, can be summarized as follows: a large central area expanded unilaterally to the valve-margin and presence of a short stria on the opposite side of the central area; an isolated stigma positioned almost in between the proximal raphe ends (surrounded by a narrow collar-shaped ring in internal view in SEM); transapical striae radiate, mainly constituted by one row of areolae covered by papillae (clearly discernible in SEM).

The characteristics of the river epilithic populations studied (Figs 80-242: LM) correspond better to the illustrations of GRUNOW and $M$. SCHмIDT than to the description and illustration of Hustedt (1930) and the description of KRAMMER \& LANGE-BERTALOT (1986), regarding the valve outline and ranges of length and width. The SEM micrographs (Figs 243-252) correspond well to the internal view presented by REICHARDT \& LANGE-BERTALOT (1991) regarding to the presence of the opening of the stigma surrounded by a collar-shaped ring and the striae formed by one row of areolae covered by papillae. Nevertheless, the natural populations studied are slightly different from GruNOw's iconotype because of the presence of one short stria in the stigma-bearing side instead of two not shortened striae.

\section{Geometric morphometric analysis}

Ageometric morphometric analysis was performed in order to justify the separation of Gomphonema rosenstockianum and $G$. tergestinum based on the valve outline, the relative dimensions of the central area and the position of the stigma. The results of the Principal Component Analysis on landmark normalized coordinates clearly demonstrated the differentiation between the two taxa, along the second PC axis (Fig. 293), considering the dimensions of the central area and the position of the stigma, proving the validity of these morphological criteria. The explained variance for the first axis (PCA1) is $74.71 \%$ and is 9.15\% for the second axis (PCA2). Comparing the morphometric data, there are highly significant differences between both species (Hotelling's multivariate discriminant test $\mathrm{T}^{2} ; \mathrm{p}<0.001$ ).

\section{Gomphonema angustius E. REICHARDT 2009 Figs 253-265: LM, Figs 283-287: SEM}

References and illustrations

This species has recently been described from Germany (Kurzenaltheim, Lkr. WUG, Bavaria) and is illustrated in REICHARDT (2009, figs 9-26: LM, figs 27-30: SEM).

\section{Morphological examination}

The population of $G$. angustius from Arba River, Zaragoza, Spain (Figs 253-265: LM, Figs 283287: SEM) corresponds well to the description of the type from Bavaria, Germany by REICHARDT (2009). Nevertheless, the Spanish specimens are 
bigger, presenting a higher length (14.8-35.0 $\mu \mathrm{m})$, a wider range of valve width $(4.2-6.9 \mu \mathrm{m})$ and showing a lower density of striae $(8-10$ in $10 \mu \mathrm{m})$. The SEM analysis showed that the striae are composed by a double row of areolae with a certain tendency to be single-rowed in the proximity of the raphe near the central area (Figs 283, 284); the striae are formed by round, dot-like areolae in external view; the areolae are not covered by papillae in internal view (Figs $285,287)$ and the internal opening of the stigma is surrounded by a collar-shaped ring (Fig. 287). These ultrastructural characteristics are also present in the illustrations of the German type material provided by ReICHARDT (2009). The morphometric characteristics of the river epilithic population studied are presented in Table 2.

During the present study, G. angustius has been found in Spain and Italy (Sicily) where it was never a dominant species and co-existed with $G$. tergestinum. In LM it can be distinguished either from G. rosenstockianum or from G. tergestinum by the valve outline and the lower density of striae and in SEM by the areolae not covered by papillae, arranged in a double row and by the opening of the stigma surrounded by a collar-shaped ring. This latter characteristic helps to distinguish this species only from $G$. rosenstockianum, being also a typical character to G. tergestinum.

\section{Gomphonema supertergestinum E. REICHARDT 2009}

Figs 266-282: LM, Figs 288-292: SEM

References and illustrations

This species has only recently been described from Germany (Hardenbecker Haussee in Boitzenburg, Uckermark, Brandenburg) and illustrated by REICHARDT (2009, figs 66-81: LM, figs 93-96: SEM).

\section{Morphological examination}

In this study, Gomphonema supertergestinum has been found in epilithic samples from several European watercourses from Bulgaria, Hungary, Slovakia and Spain, co-existing in some of them with $G$. tergestinum.

The populations of G. supertergestinum from Nela River (Burgos, Spain) (Figs 266-274: LM, Figs 288-292: SEM) and Danube River main arm (Göd, Hungary) (Figs 275-282: LM) correspond well to the description of the species by REICHARDT (2009). However, the populations from Spain and Hungary are smaller (25.2-38.7 $\mu \mathrm{m}$ length, $6.7-8.5 \mu \mathrm{m}$ width) than presented in the diagnosis of the species and show a narrower range of density of striae $(9-11$ in $10 \mu \mathrm{m})$. Additionally, a row of poroids in the cingulum is visible in girdle view (Fig. 274).

In SEM some characteristics referred to and illustrated by REICHARDT (2009) are visible, like the pseudoseptum in the headpole (Fig. 290), the striae composed by a double row of areolae with some tendency to be uniseriate near the raphe (especially the striae delimiting the central area) (Fig. 291), the areolae not covered by papillae in internal view (Fig. 292), the internal opening of the stigma surrounded by a collar-shaped ring (Fig. 292) and the striae formed by round, dot-like areolae in external view (Fig. 291). The morphometric characteristics of the river epilithic populations studied are presented in Table 2.

Despite the co-occurrence of $G$. supertergestinum with $G$. tergestinum, it can be easily distinguished from G. tergestinum as well as from $G$. rosenstockianum in LM by the more robust valve outline, larger dimensions and lower density of striae in $10 \mu \mathrm{m}$ in G. supertergestinum. In SEM the areolae not-covered by papillae and arranged in double rows can separate it from $G$. tergestinum and $G$. rosenstockianum while the internal opening of the stigma surrounded by a collar-shaped ring can help to differentiate it from $G$. rosenstockianum. The more robust valve outline and larger dimensions can facilitate the discrimination of this species from $G$. angustius. Morphometric and ultrastructural characteristics that allow the distinction between these four taxa are presented in Table 3.

\section{Biogeography of Gomphonema rosenstockia- num and G. tergestinum species complex}

Subsequently to the revision of the literature published about this Gomphonema species complex, and taking into account the information provided by the analysis of the samples in this study, maps with world and European distribution of $G$. tergestinum, $G$. rosenstockianum, $G$. angustius, and $G$. supertergestinum have been performed, as shown in Figs 294 and 295.

\section{Discussion and conclusions}

The observations of type material, literature data and field populations from different European rivers made during this study allowed the identification of the following morphological 


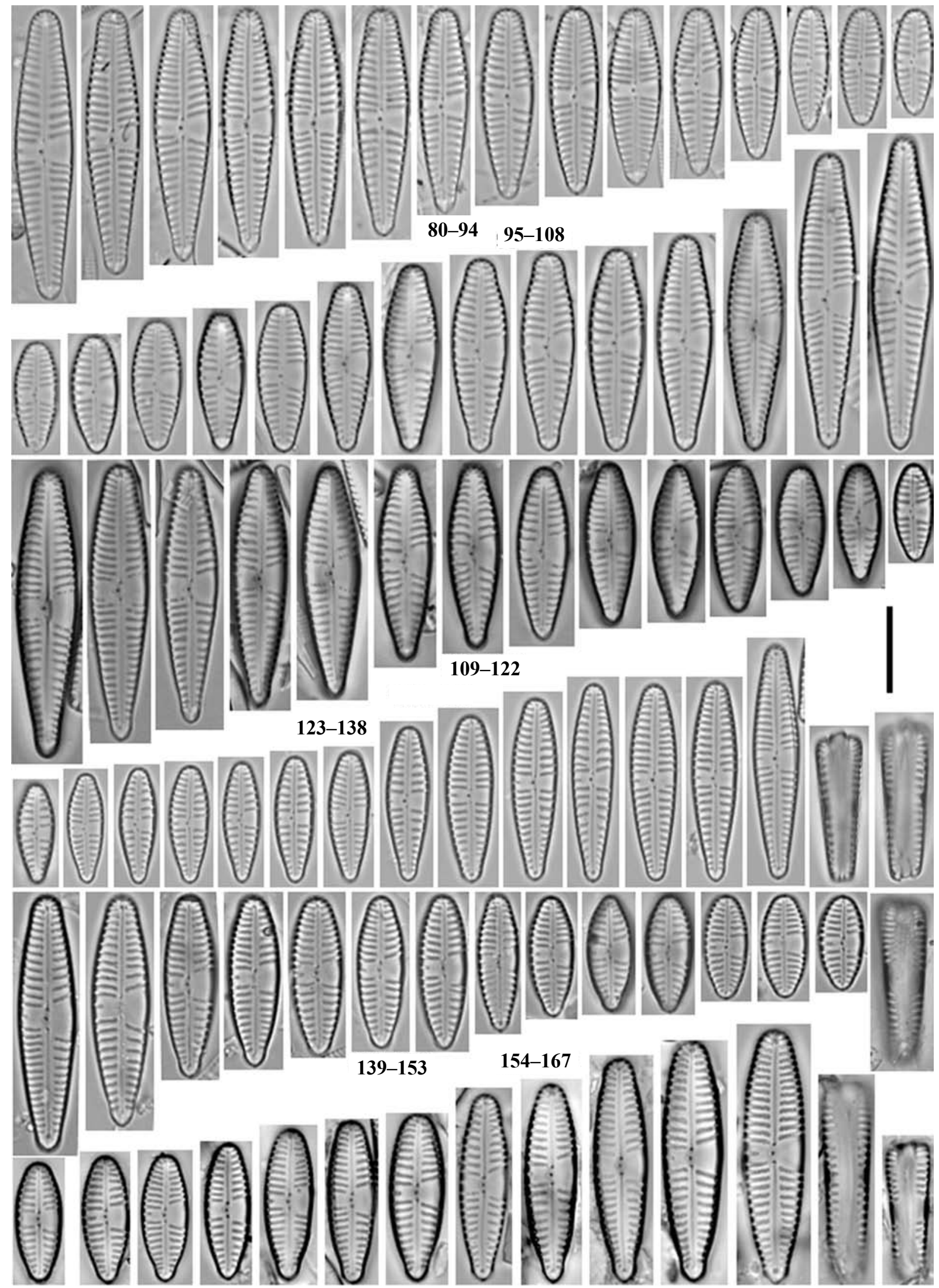

Figs 80-167. Light micrographs of Gomphonema tergestinum: (80-94) Cant Stream, Biancot, Cuneo, Italy; (95-108) Germanasca Stream, Ghigo di Prali, Torino, Italy; (109-122) Payant Stream, Bobbio Pellice, Torino, Italy; (123-138) Drôme River, Charens, Rhone Alps, France; (139-153) Danube River, Karlova Ves, Slovakia; (154-167) Lomnica River, Juskova Vola, Slovakia. Scale bar $10 \mu \mathrm{m}$. 

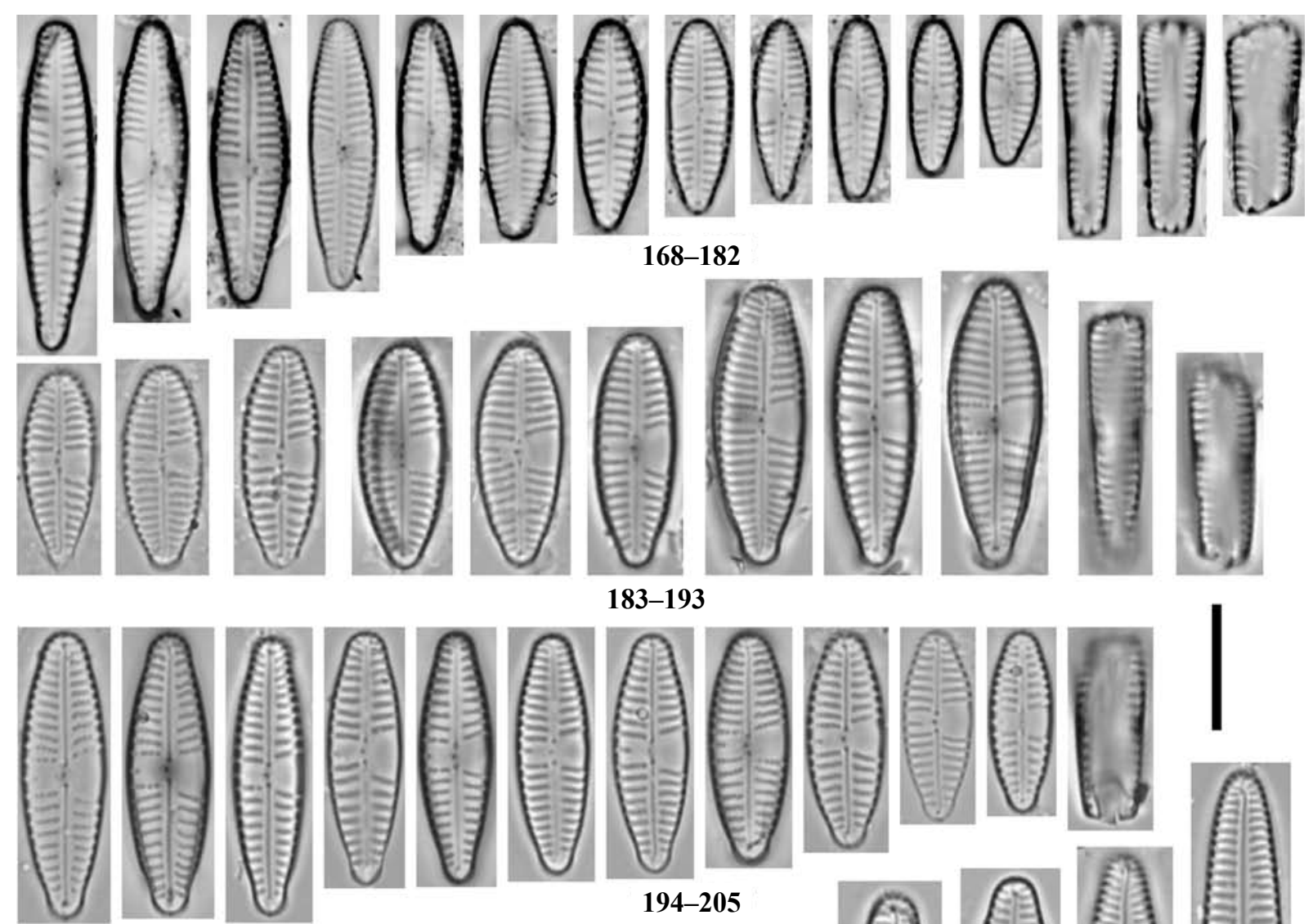

183-193
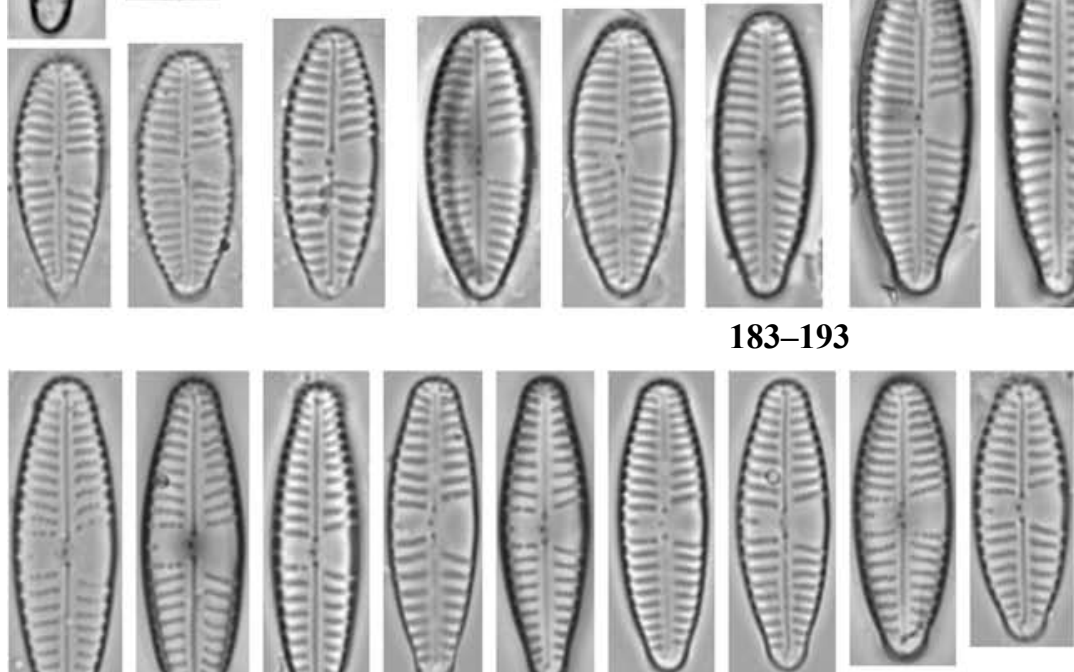

194-205
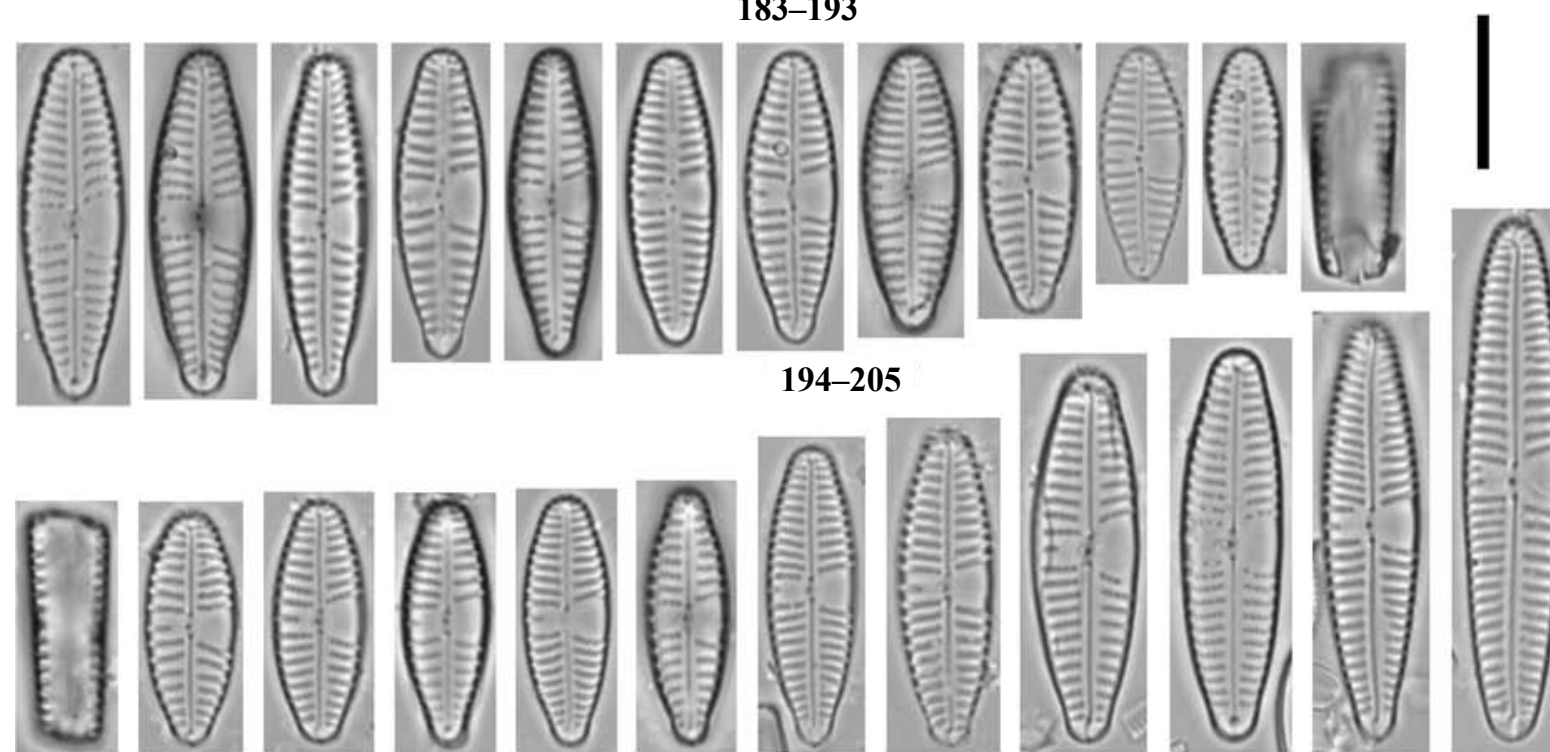

206-217
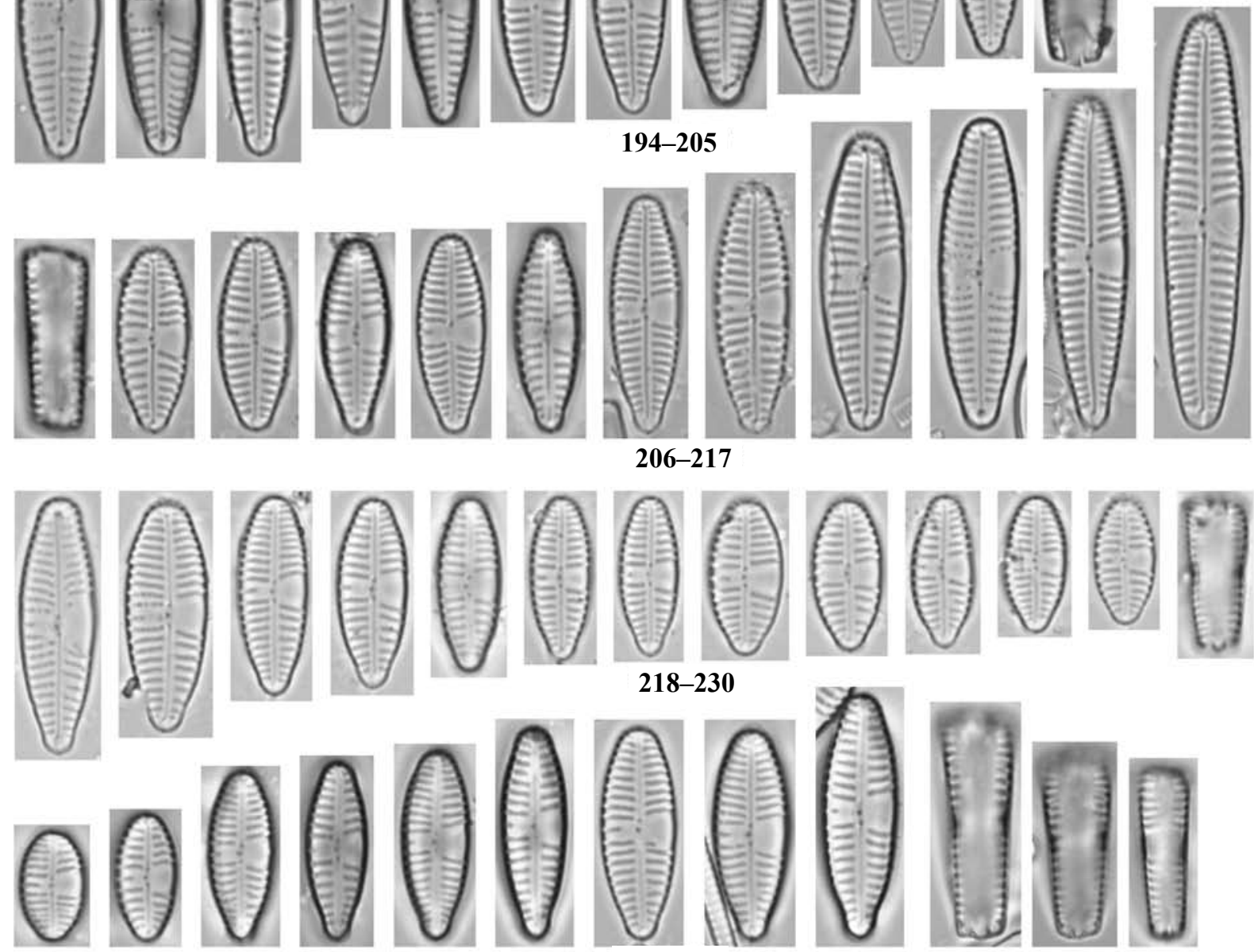

231-242

Figs 168-242. Light micrographs of populations of Gomphonema tergestinum from Spain: (168-182) Isuela River, Ermita de San Roque, Cálcena, Zaragoza; (183-193) Araquil River, Asiaín, Navarra; (194-205) Esca River, Sigües, Zaragoza; (206-217) Arga River, Huarte, Navarra; (218-230) Ebro River, San Adrián, Navarra; (231-242) Arga River, Embalse Eugui, Navarra. Scale bar $10 \mu \mathrm{m}$. 


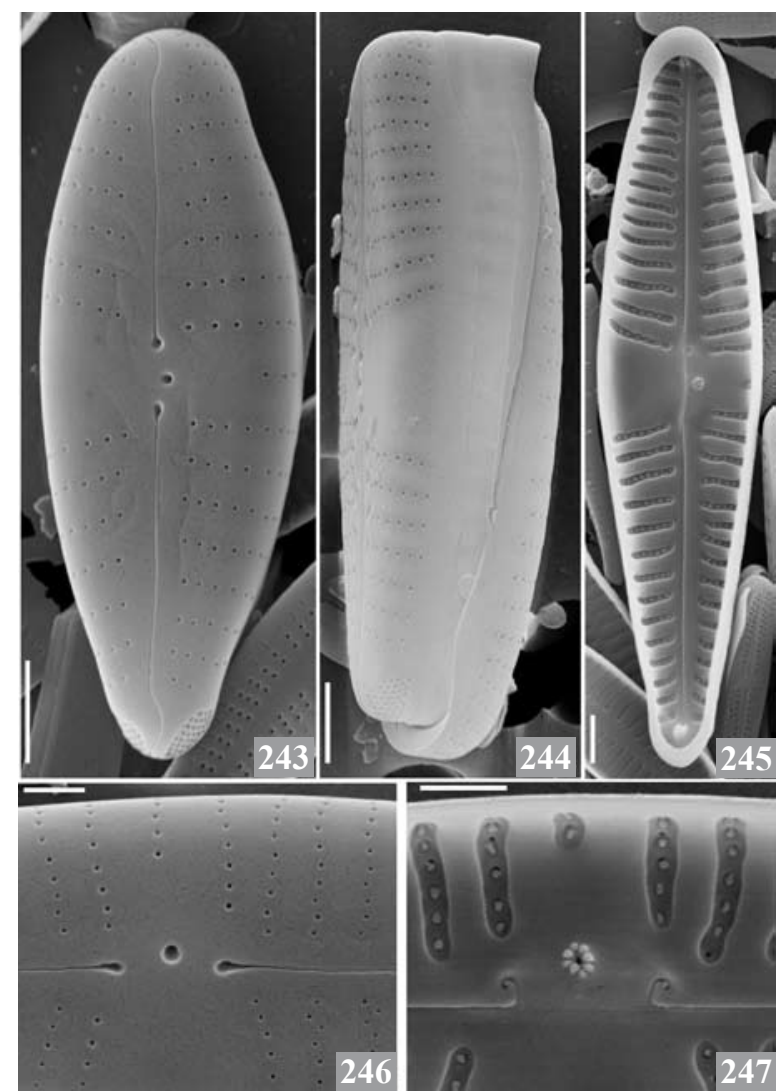

Figs 243-247. Scanning electron micrographs of Gomphonema tergestinum from Payant Stream, Bobbio Pellice, Torino, Italy: (243) valvar external view; (244) girdle external view from Fiumedinisi, Sicily, Italy; (245) valvar internal view, showing the uniseriate striation and the areolae covered by papillae; $(246,247)$ details of the central area in external (Fig. 246) and internal (Fig. 247) view, presenting the stigma surrounded by a collar-shaped ring in internal view. Scale bars (Figs 243-245) $2 \mu \mathrm{m}$; scale bars (Figs 246, 247) $1 \mu \mathrm{m}$.

criteria to reliably distinguish between $G$. rosenstockianum and $G$. tergestinum: 1) the presence of a collar-shaped ring around the opening of the stigma in internal view in $G$. tergestinum (only visible by SEM) and its absence in G. rosenstockianum (the stigma is instead covered by a papilla); 2) the more central position of the stigma situated almost in between proximal raphe ends in $G$. tergestinum (visible by LM and SEM on external view); 3) the more evident stigma in G. tergestinum (LM); 4) the presence of a wider central area in $G$. tergestinum with the striae of the central area more radiate while in $G$. rosenstockianum these striae are usually more parallel.

The geometric morphometric analysis proved to be a useful tool and allowed the validation of these criteria and the subsequent separation of both species. This approach has

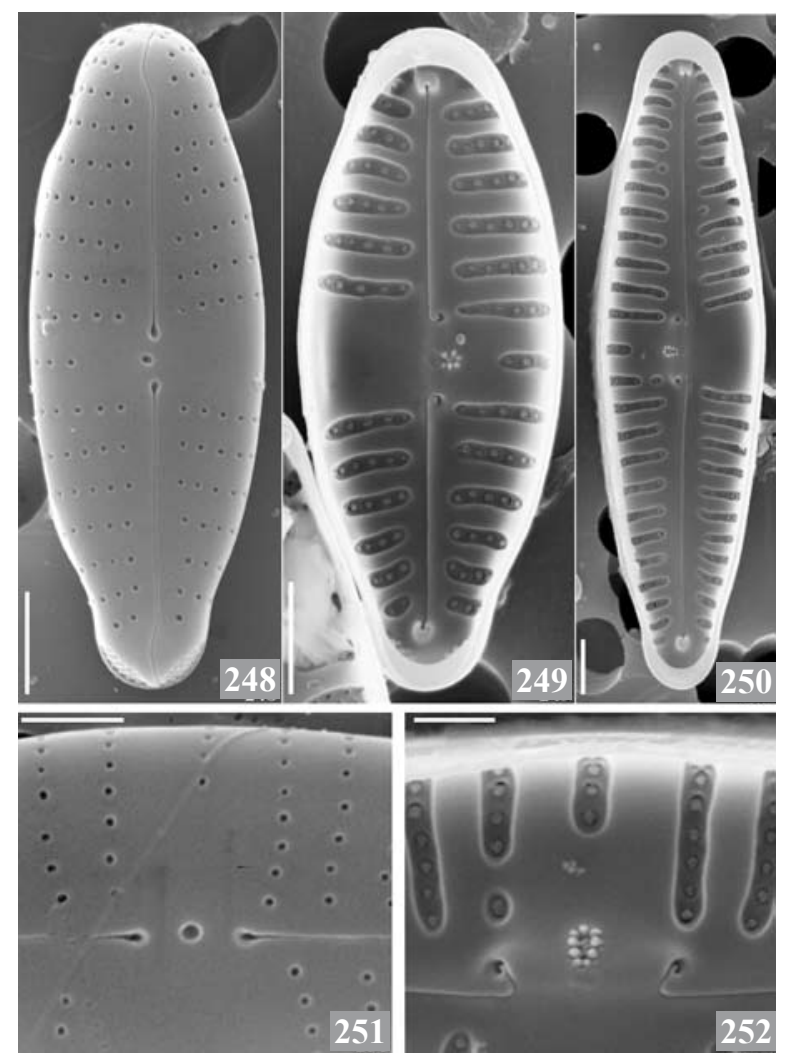

Figs 248-252. Scanning electron micrographs of Gomphonema tergestinum from Arga River, Embalse Eugui, Navarra, Spain: $(248)$ valvar external view; $(249,250)$ valvar internal view; $(251,252)$ details of the central area in internal (Fig. 251) and external (Fig. 252) view. Scale bars (Figs 248250) $2 \mu \mathrm{m}$; scale bars (Figs 251, 252) $1 \mu \mathrm{m}$.

become a standard tool of taxonomic studies due to its higher capacity to distinguish shapes, and proved to be a useful tool in clarifying difficult species complexes such as Achnanthidium KüTZING (Potapova et Hamilton 2007) or Reimeria sinuata and Gomphonema tergestinum (FránKová et al. 2009).

The biogeography of these Gomphonema species can also be helpful in distinguishing them, since G. rosenstockianum has only been found in the Canary Islands and Mediterranean region (Balearic Islands, Cyprus and South of Portugal) (Fig. 295) up to now. G. tergestinum seems to be widespread all over the world, although being mainly a palearctic species (Fig. 294). As regards to the ecology of $G$. rosenstockianum, the analysis of the chemical parameters of the sites where the natural samples were collected allowed the confirmation of the information already provided by LANGE-BERTALOT (1993): G. rosenstockianum is an alcaliphilous species, mainly occurring in oligo- to $\beta$-mesosaprobic waters, although it can also be found in $\alpha$-mesosaprobic waters. In the 

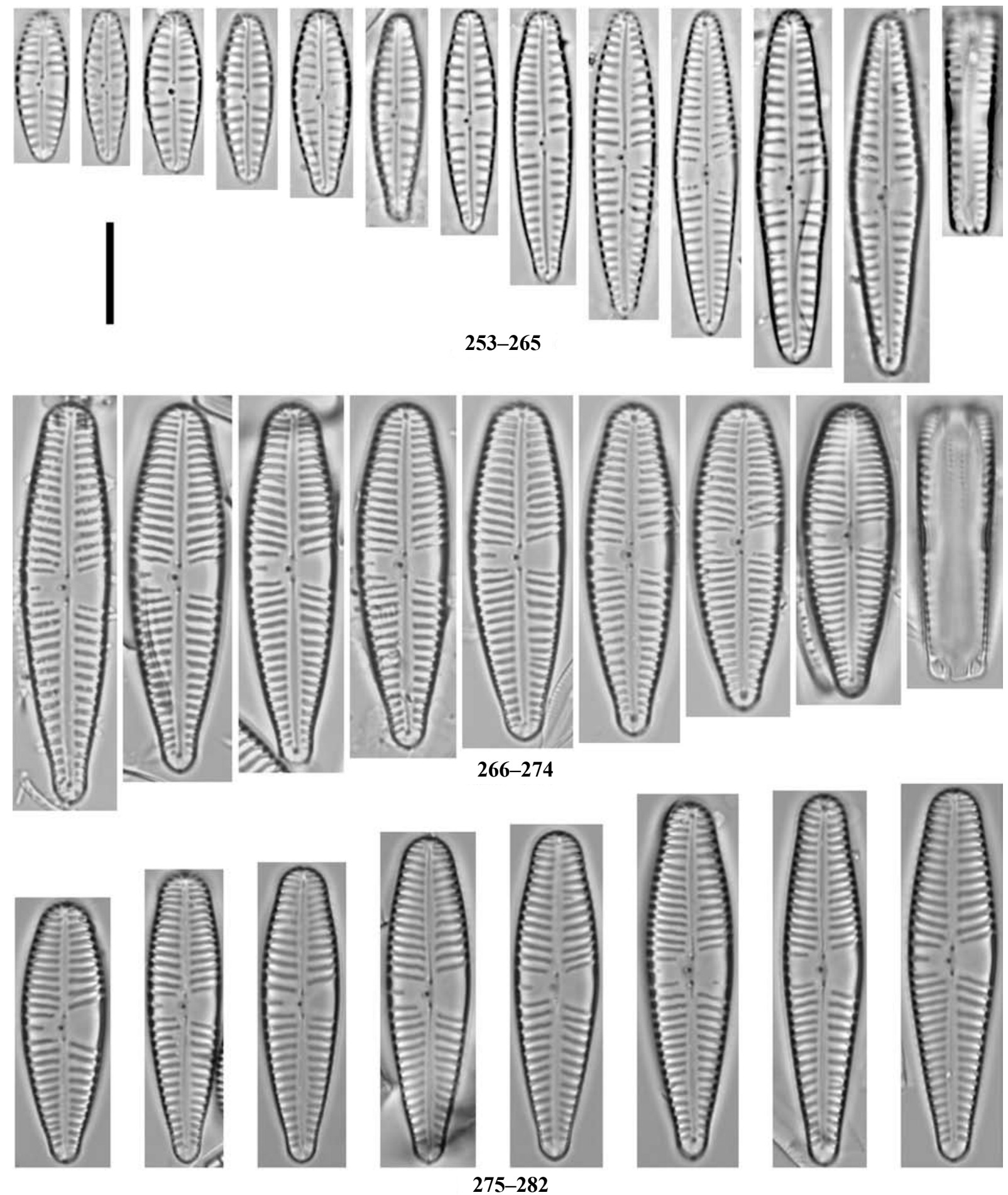

Figs 253-265. Light micrographs of Gomphonema angustius from Arba de Biel River, Luna, Zaragoza, Spain.

Figs 266-282. Light micrographs of Gomphonema supertergestinum: (266-274) Nela River, Cigüenza, Villarcayo, Burgos, Spain; (275-282) Danube main arm, Göd, Hungary. Scale bar $10 \mu \mathrm{m}$. 


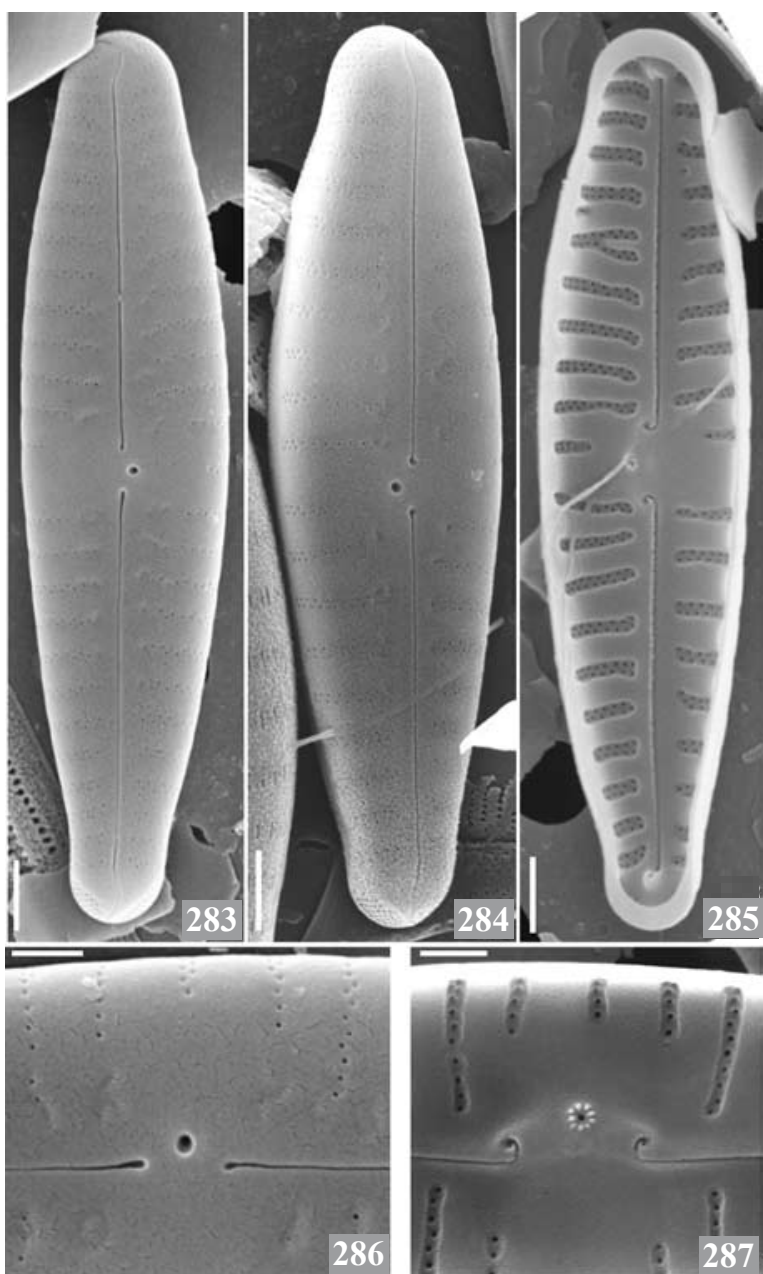

Figs 283-287. Scanning electron micrographs of Gomphonema angustius from Arba River, Biel in Luna, Zaragoza, Spain: (283, 284) valvar external view; (285) valvar internal view, presenting the biseriate striation; (286, 287) details of the central area in external (Fig. 286) and internal (Fig. 287) view, showing the areolae not covered by papillae and the stigma surrounded by a collar-shaped ring. Scale bars (Figs 283-285) $2 \mu \mathrm{m}$; scale bars (Figs 286, 287) $1 \mu \mathrm{m}$.

light of the presented results, several pictures of G. rosenstockianum referred from Bulgaria in reality belong to $G$. tergestinum (Ivanov et al. 2006a, figs 16-18; IvanOv et al. 2006b, pl. 7, figs 2, 3; Stancheva et al. 2007, pl. 3, figs 1-4).

Furthermore, the examination of the bibliographic references about $G$. tergestinum made clear that also the species G. supertergestinum has been previously incorrectly identified as $G$. tergestinum by SCHмIDT et al. (1902, figs 39, 40), Hustedt (1930, fig. 717), VAN DER WerfF \& Huls (1957-1974), Krammer \& Lange-Bertalot (1986, pl. 162, figs 6, 7), Ivanov et al. (2006a, p. 332, fig. 19), LevKov et al. (2007, pl. 166, fig. 17), and as G. rosenstockianum by Ivanov et al. (2006b, pl. 7,

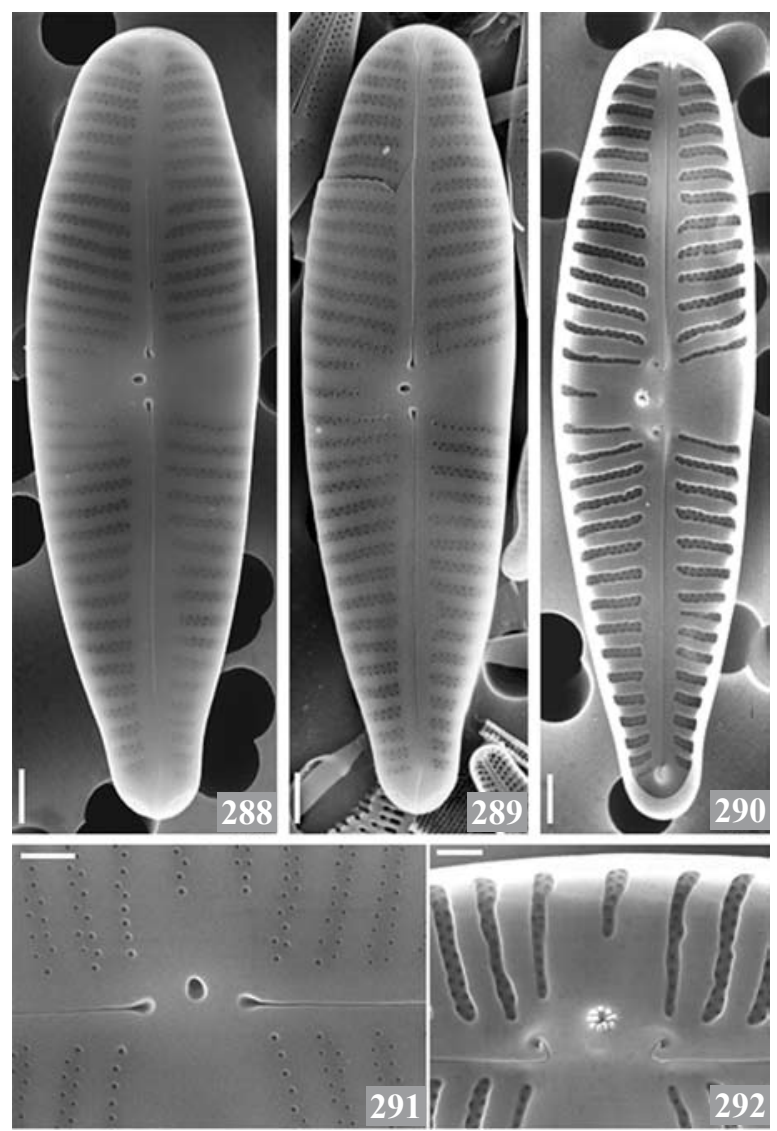

Figs 288-292. Scanning electron micrographs of Gomphonema supertergestinum from Nela River, Cigüenza, Villarcayo, Burgos, Spain: $(288,289)$ valvar external view, presenting the biseriate striation; (290) valvar internal view; (291, 292) details of the central area in external (Fig. 291) and internal (Fig. 292) view, showing the areolae not covered by papillae and the stigma surrounded by a collar-shaped ring. Scale bars (Figs 288-290) $2 \mu \mathrm{m}$; scale bars (Figs 291, 292) $1 \mu \mathrm{m}$.

fig. 1) and Stancheva et al. (2007, pl. 3, figs 5, 6). Noticeably, most of these references correspond to lentic habitats, thus confirming the ecological preferences of $G$. supertergestinum for standing waters as noticed by ReICHARDT (2009). Indeed the samples studied in this work were collected in large rivers, where sometimes the diatoms could only be collected near the margins, consequently in zones with low water flow and with more lentic characteristics.

Gomphonema angustius can be misidentified as G. angustum C. AgardH or G. occultum E. Reichardt \& LANGE-Bert. in LM by the valve outline, similar striation pattern and position of the stigma. Although REICHARDT (2009) stated that $G$. angustius can be smaller (narrower) than $G$. angustum, the population studied in this work was wider than the type material of $G$. angustius. 


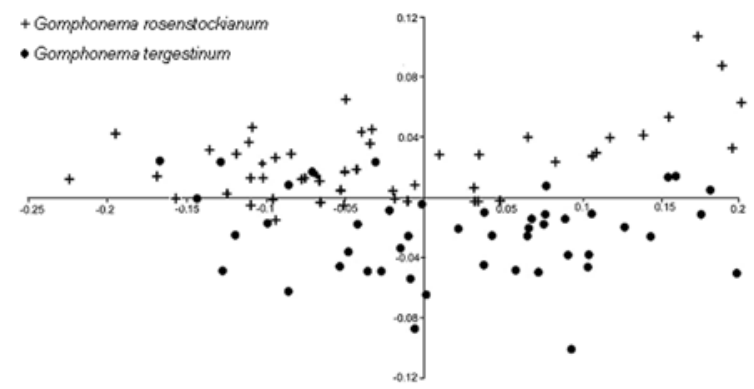

Fig. 293. Principal Component Analysis (PCA) plot of normalized coordinates for the morphological landmarks digitized on LM images of selected populations of Gomphonema rosenstockianum (cross) and G. tergestinum (circle).

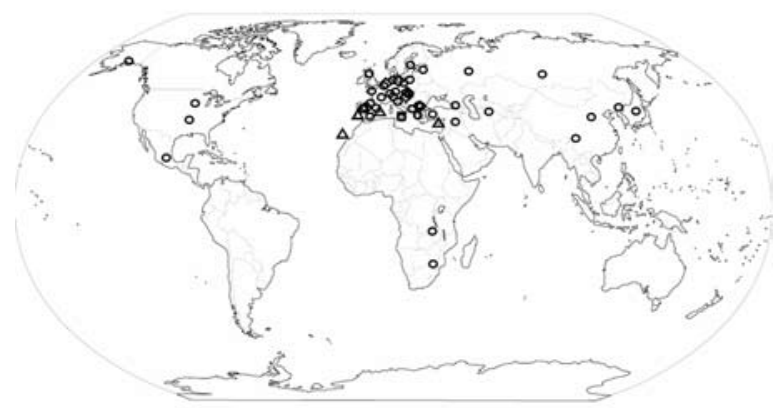

Fig. 294. World distribution map of Gomphonema rosenstockianum (triangle), $G$. tergestinum (circle), $G$. angustius (square), G. supertergestinum (diamond).

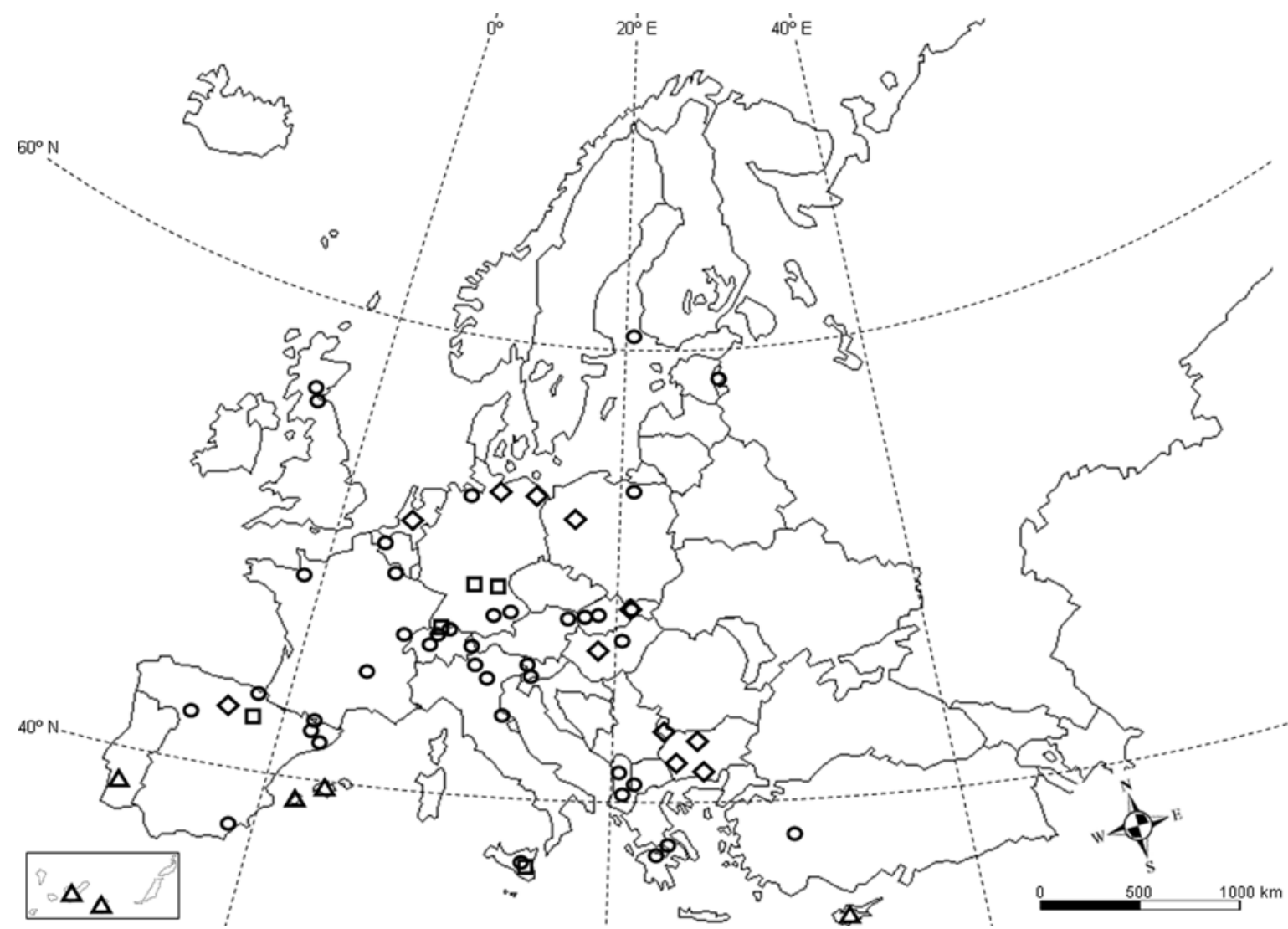

Fig. 295. European distribution map of Gomphonema rosenstockianum (triangle), G. tergestinum (circle), G. angustius (square), G. supertergestinum (diamond).

Therefore, we conclude that these three species can only be distinguished with certainty in SEM. G. angustius differs from $G$. angustum and from G. occultum by the areolae not covered by papillae and arranged in double rows; additionally $G$. angustius is distinguished from $G$. angustum by the more recurved hook-shaped proximal raphe ends (REICHARDT \& LANGE-BERTALOT 1991).

Regarding the general morphology of the species complex presented, mostly biseriate striation of $G$. angustius (Figs 283-285) and $G$. supertergestinum (Figs 288-290) could induce questions whether the placement of these species in the genus Gomphonema is justified. The taxonomic position of the double punctate species within the genera Gomphonema or Gomphoneis without longitudinal lines has already been discussed in the last decades, allowing different opinions. According to DAwsON (1974) and TUJI (2005), species presenting double rows of simple 
Table 2. Morphometric data of the Gomphonema studied (underlined = type material).

Sample size: G. rosenstockianum, $n=61 ;$. tergestinum, $n=148 ;$. angustius, $n=12$; G. supertergestinum, $n=16$.

\begin{tabular}{|c|c|c|c|}
\hline Species / Sites & $\begin{array}{c}\text { Length } \\
(\mu \mathrm{m})\end{array}$ & $\begin{array}{l}\text { Width } \\
(\mu \mathrm{m})\end{array}$ & $\begin{array}{c}\text { Number of striae } \\
\text { in } 10 \mu \mathrm{m}\end{array}$ \\
\hline \multicolumn{4}{|l|}{ G. rosenstockianum LANGE-BERT. \& E. ReICHARDT } \\
\hline La Gomera, Canary Islands (Spain) & $16.7-34.0$ & $4.9-6.3$ & $10-13$ \\
\hline Arão Stream, Algarve (Portugal) & $10.1-29.6$ & $4.8-5.7$ & $12-16$ \\
\hline Algibre Stream, Algarve (Portugal) & $10.1-32.8$ & $4.5-6.1$ & $12-15$ \\
\hline Son Brull Stream, Mallorca Island (Spain) & $9.7-29.7$ & $4.6-5.8$ & $11-15$ \\
\hline Puigpunyent Stream, Mallorca Island (Spain) & $10.9-34.0$ & $4.4-6.2$ & $10-17$ \\
\hline \multicolumn{4}{|l|}{ G. tergestinum (Grunow) M. SсHмIDT } \\
\hline Trieste (Italy) & 14.0 & 3.5 & 14 \\
\hline Cant Stream, Cuneo (Italy) & $11.1-30.1$ & $4.1-6.0$ & $11-14$ \\
\hline Germanasca Stream, Torino (Italy) & $11.4-32.7$ & $4.3-6.3$ & $10-16$ \\
\hline Payant Stream, Torino (Italy) & $11.1-30.1$ & $4.1-6.0$ & $11-14$ \\
\hline Drôme River, Charens, Rhone Alps (France) & $11.6-26.6$ & $4.0-5.3$ & $11-15$ \\
\hline Danube River (Slovakia) & $9.5-26.4$ & $4.4-5.7$ & $11-15$ \\
\hline Lomnica River (Slovakia) & $12.3-26.4$ & $4.9-6.0$ & $10-16$ \\
\hline Isuela River, Zaragoza (Spain) & $9.9-23.3$ & $3.6-5.4$ & $10-14$ \\
\hline Araquil River, Navarra (Spain) & $13.4-20.1$ & $5.0-6.5$ & $11-15$ \\
\hline Esca River, Zaragoza (Spain) & $12.6-20.1$ & $4.2-5.9$ & $10-14$ \\
\hline Arga River, Huarte, Navarra (Spain) & $13.3-29.7$ & $5.1-6.0$ & $12-14$ \\
\hline Ebro River, San Adrián, Navarra (Spain) & $10.0-20.7$ & $4.7-6.3$ & $12-14$ \\
\hline Arga River, Embalse Eugui, Navarra (Spain) & $8.7-20$ & $4.7-5.8$ & $9-14$ \\
\hline \multicolumn{4}{|l|}{ G. angustius E. REICHARDT } \\
\hline Kurzenaltheim, Lkr. WUG, Bavaria (Germany) & $10.3-26.0$ & $4.0-5.6$ & $10-12$ \\
\hline Arba de Biel River, Luna, Zaragoza (Spain) & $14.8-35.0$ & $4.2-6.9$ & $8-10$ \\
\hline \multicolumn{4}{|l|}{ G. supertergestinum E. REICHARDT } \\
\hline Boitzenburg, Uckermark, Brandenburg (Germany) & $22.0-52.0$ & $7.0-9.8$ & $9-12$ \\
\hline Nela River, Burgos (Spain) & $28.1-38.7$ & $7.0-8.0$ & $10-11$ \\
\hline Danube main arm, Göd (Hungary) & $25.2-36.2$ & $6.7-8.5$ & $9-11$ \\
\hline
\end{tabular}

pores instead of the reniform poroidal structure typical of Gomphonema should be placed in the genus Gomphoneis. MERINo et al. (1994) also suggested the placement in the genus Gomphoneis of Gomphonema rhombicum M. SchMIDT, based on the presence of septa and pseudosepta in the headpole and striae composed by double rows of single pores; however, the latter species lacks the longitudinal lines. Other authors, such as IsERENTANT \& ECTOR (1996) and ReichardT (2007), state that the arrangement of areolae in double rows is more common than has been suggested and can be found in all groups of the genus Gomphonema, even in taxa closely related 


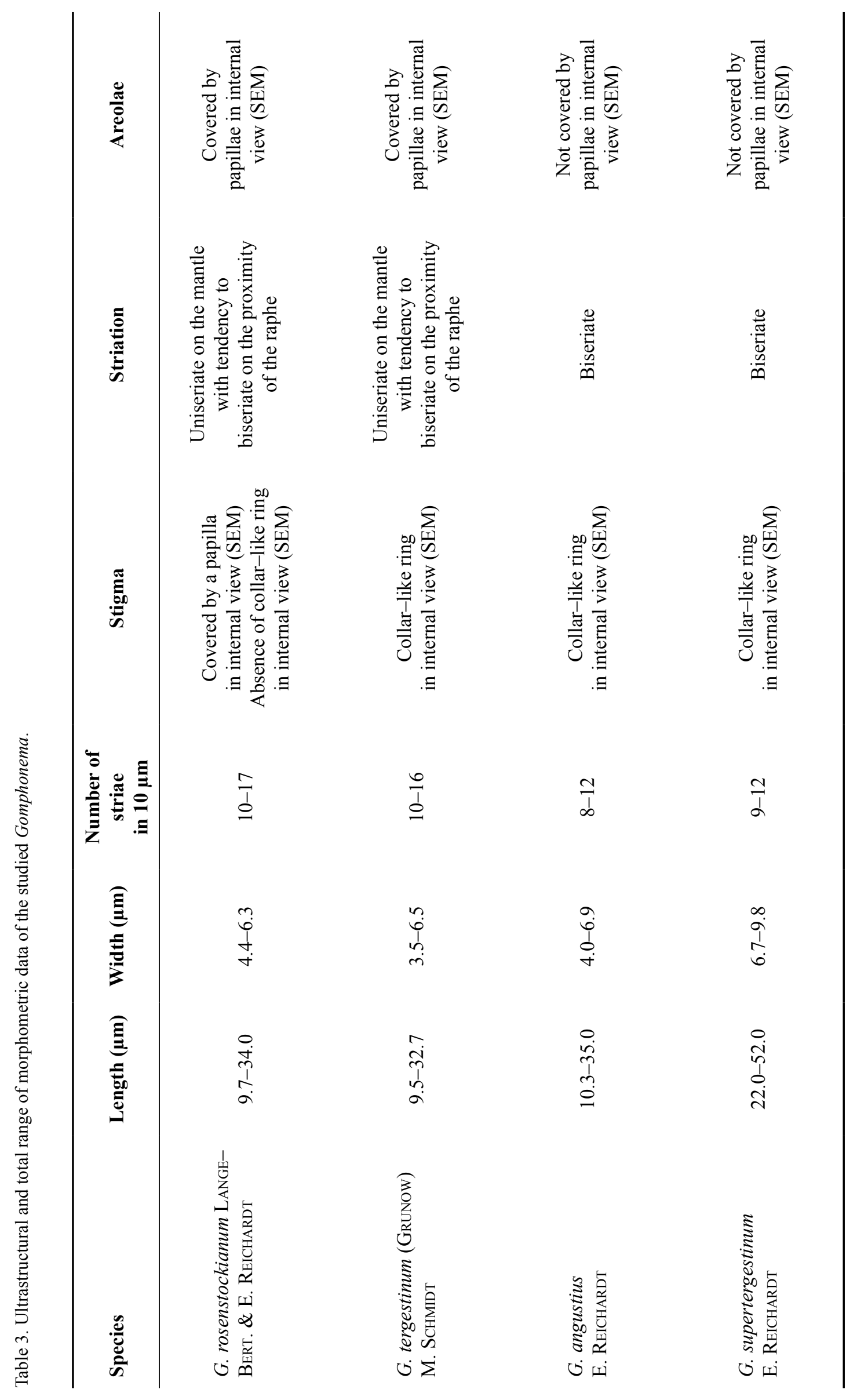


to the generic type. Furthermore, G. angustius (Fig. 283), G. supertergestinum (Figs 288, 291) and also other species such as Rhoicosphenia abbreviata (C. AgARdH) LANGe-Bert. can even present both uniseriate and biseriate striae within the same valve (LANGE-BERTALOT 1980), which evokes doubts about the taxonomic relevance of this character on the generic level. Therefore we consider the criterion of double punctuation as not sufficient to place these species in the genus Gomphoneis.

Apart of double rows of simple pores, $G$. supertergestinum also presents a pseudoseptum in the bluntly rounded headpole; nevertheless, in our opinion, this species should be kept in the genus Gomphonema. The genus Gomphoneis is still not clearly defined since it is a rather heterogeneous group lacking reliable and clear characters to allow its differentiation from the genus Gomphonema, as pointed out by REICHARDT (2007).

From our study it becomes clear that there are recognizable differences in the ecological preferences of the taxa within this group, which can also serve as a helpful tool for the identification. It would thus be interesting to perform a similar study at a wider geographical scale, in order to increase and to support the current knowledge about the taxonomy, autoecology and biogeography of this species complex. Furthermore, it would be very useful to include the investigation of other species belonging to the same group, such as $G$. angustum and G. occultum.

\section{Acknowledgements}

This project was supported by Fundação para a Ciência e a Tecnologia - Portugal (grant SFRH/ $\mathrm{BD} / 21625 / 2005$ ), by the project "Impact of forest fires on ecological quality of Monchique streams" funded by the Fundação para a Ciência e Tecnologia project $\mathrm{n}^{\circ} \mathrm{POCI} / \mathrm{AMB} / 60266 / 204$ and by the Public Research Centre - Gabriel Lippmann (Luxembourg).

We gratefully acknowledge Christophe Bouillon for the SEM technical assistance, Damien Marion for the assistance with the German translations, Carlos E. Wetzel for his valuable suggestions on the manuscript, and Dr. Horst Lange-Bertalot for providing the type material of G. rosenstockianum.

\section{References}

CARTer, J.R. (1960): Diatom notes. British freshwater forms of the genus Gomphonema. - The Microscope 12: 255-264.
Cleve, P.T. (1894): Synopsis of the Naviculoid Diatoms, Part I. - Kongliga Svenska-Vetenskaps Akademiens Handlingar 26: 1-194, 5 pls.

Cleve-Euler, A. (1955): Die Diatomeen von Schweden und Finnland. Part IV. Biraphideae 2. - Kongliga Svenska Vetenskaps-Akademiens Handligar, ser. 4, 5: 1-232, figs 971-1306.

Dawson, P. (1974): Observations on diatom species transferred from Gomphonema C. A. AgARDH to Gomphoneis Cleve. - Brit. Phycol. J. 9: 75-82.

EhrenberG, C.G. (1832): Über die Entwicklung und Lebensdauer der Infusionsthiere; nebst ferneren Beiträgen zu einer Vergleichung ihrer organischen Systeme. - Abh. Königl. Akad. Wiss. Berlin 1831: 1-154, 4 pls.

Fránková, M., PoulíčKová, A., Neustupa, J., Pichrtová, M. \& Marvan, P. (2009): Geometric morphometrics - a sensitive method to distinguish diatom morphospecies: a case study on the sympatric populations of Reimeria sinuata and Gomphonema tergestinum (Bacillariophyceae) from the River Becva, Czech Republic. - Nova Hedwigia 88: 81-95.

GÜTTINGER, W. (1992): Collection of SEM micrographs of diatoms. Series 6. CH-6984 Pura, Switzerland.

Hammer, Ø., Harper, D.A.T. \& Ryan, P.D. (2001): PAST: Paleontological Statistics Software Package for Education and Data Analysis. Palaeont. Electr. 4: 1-9.

Hotelling, H. (1931): The generalization of Student's ratio. - Ann. Math. Statist. 2: 360-378.

Hürlimann, J. \& Niederhauser, P. (2007): Méthodes d'analyse et d'appréciation des cours d'eau. Diatomées Niveau $\mathrm{R}$ (région). État de l'environnement $\mathrm{n}^{\circ}$ 0740. - $122 \mathrm{pp}$., Office fédéral de l'environnement, Berne.

Hustedt, F. (1930): Bacillariophyta (Diatomeae). In: PAscher, A. (ed.): Die Süsswasserflora von Mitteleuropa 10. - 466 pp., Gustav Fischer, Stuttgart - Jena.

ISERENTANT, R. \& ECTOR, L. (1996): Gomphonema rhombicum M. SchMidT (Bacillariophyta): typification et description en microscopie optique. - Bull. Fr. Pêche Piscic. 341/342: 115124.

Ivanov, P., Kirilova, E. \& Ector, L. (2006a): Diatom taxonomic composition of rivers in South and West Bulgaria. - Phytol. Balcan. 12: 327-338.

Ivanov, P., Kirilova, E. \& Ector, L. (2006b): Diatom species composition from the River Iskar in the Sofia region, Bulgaria. - In: OgnJanovaRumenova, N. \& ManoYlov, K. (eds): Advances in Phycological Studies. - pp. 167-190, Pensoft Publishers and University Publishing House, Sofia-Moscow.

Krammer, K. \& LAnge-Bertalot, H. (1986): Bacillariophyceae 1. Teil: Naviculaceae. 
- In: Ettl, H., Gerloff, J., Heynig, H. \& Mollenhauer, D. (eds): Süßwasserflora von Mitteleuropa 2/1.-876 pp., G. Fischer, Stuttgart $\&$ New York.

Lange-Bertalot, H. (1980): Ein Beitrag zur Revision der Gattungen Rhoicosphenia GRUN., Gomphonema C. AG., Gomphoneis CL. - Bot. Not. 133: 585-594.

Lange-Bertalot, H. (1993): 85 neue Taxa und über 100 weitere neu definierte Taxa ergänzend zur Süßwasserflora von Mitteleuropa 2/1-4. Bibliotheca Diatomologica 27: 1-454.

LAnge-Bertalot, H. (1996): Rote Liste der limnischen Kieselalgen (Bacillariophyceae) Deutschlands. - Schriftenreihe Vegetationsk. 28: 633-677.

Lange-Bertalot, H. \& Metzeltin, D. (1996): Oligotrophie-Indikatoren. $\quad 800 \quad$ Taxa repräsentativ für drei diverse Seen-Typen Kalkreich-Oligodystroph-Schwach gepuffertes Weichwasser. - In: LANGe-Bertalot, H. (ed.): Iconographia Diatomologica. Annotated Diatom Micrographs Vol. 2. - 390 pp., Koeltz Scientific Books, Koenigstein.

Levkov, Z., Krstic, S., Metzeltin, D. \& Nakov, T. (2007): Diatoms from Lakes Prespa and Ohrid. - In: Lange-Bertalot, H. (ed.): Iconographia Diatomologica. Annotated Diatom Micrographs 16. - 611 pp., Koeltz Scientific Books, Koenigstein.

Manguin, E. (1964): Contribution à la connaissance des diatomées des Andes du Pérou. - Mém. Mus. Natl. Hist. Nat., B, Bot. 12: 1-98.

Merino, V., García, J., Hernández-Mariné, M. \& Fernández, M. (1994): Morphology and ultrastructure of Gomphoneis rhombica (FRICKE) comb. nov. - Diatom Res. 9: 335-347.

Potapova, M. \& Hamilton, P.B. (2007): Morphological and ecological variation within the Achnanthidium minutissimum (Bacillariophyceae) species complex. - J. Phycol. 43: 561-575.

Reichardt, E. (2007): Neue und wenig bekannte Gomphonema-Arten (Bacillariophyceae) mit Areolen in Doppelreihen. - Nova Hedwigia 85: 103-137.

REICHARDT, E. (2009): Silikatauswüchse an den inneren Stigmenöffnungen bei Gomphonema-Arten. Diatom Res. 24: 159-173.

Reichardt, E. \& Lange-Bertalot, H. (1991): Taxonomische Revision des Artenkomplexes um Gomphonema angustum-G. dichotomum-G. intricatum-G. vibrio und ähnliche Taxa (Bacillariophyceae). - Nova Hedwigia 53: 519-544.

Robert, A. (1969): Contribution to the study of the diatoms in the northeast section of the Transylvania Plateau. - Stud. Univ. BabesBolyai, Ser. 2, Biol. 14: 39-46.

Rohlf, F.J. (2004): TpsDig, digitize landmarks and outlines, version 2.0. Department of Ecology and Evolution, State University of New York at Stony Brook. http://life.bio.sunysb.edu/morph/

Rohlf, F.J. \& Slice, D.E. (1990): Extensions of the Procrustes method for the optimal superimposition of landmarks. - Syst. Zool. 39: 40-59.

Round, F.E., Crawford, R.M. \& Mann, D.G. (1990): The Diatoms. Biology and morphology of the genera. - 747 pp., Cambridge University Press, Cambridge.

Schmidt, A., Schmidt, M., Fricke, F., Heiden, H., Müller, O. \& Hustedt, F. (1902): Atlas der Diatomaceenkunde. - Series V, 59-60: pls. 233-240, O.R. Reisland, Leipzig.

Sims, P. (1996): An atlas of British diatoms arranged by B. Hartley based on illustrations by H.G. Barber and J.R. CARTer. - 601 pp., Biopress Ltd., Bristol.

Stancheva, R., Mancheva, A. \& Ivanov, P. (2007): Taxonomic composition of the epilithic diatom flora from rivers Vit and Osum, Bulgaria. Phytol. Balcan. 13: 53-64.

Tusi, A. (2005): Taxonomy of the Gomphoneis tetrastigmata species complex. - Bull. Natn. Sci. Mus., Ser. B, 31: 89-108.

Van Dam, H., Mertens, A. \& Sinkeldam, J. (1994): A coded checklist and ecological indicator values of freshwater diatoms from the Netherlands. Neth. J. Aquat. Ecol. 28: 117-133.

VAN DER WerfF, A. \& Huls, H. (1957-1974): Diatomeënflora van Nederland. - De Hoef, Abcoude.

Van Heurck, H. (1880): Synopsis des Diatomées de Belgique. Atlas. - pl. 1-30, Ducaju \& Cie, Anvers.

(C) Czech Phycological Society

Received April 20, 2009

Accepted July 4, 2009 